\title{
THE EFFECT OF WORK ETHOS ON PERFORMANCE OF EMPLOYEES IN THE OFFICE OF CULTURE AND TOURISM OF JAYAWIJAYA REGENCY
}

\author{
Tati Haryati ${ }^{1}$ and $H$. Rudihartono Ismail ${ }^{2}$ \\ ${ }^{1,2}$ University of Amal Ilmiah Yapis Wamena, Jayawijaya Regency, Indonesia
}

\begin{abstract}
Purpose - The purpose of this research is to determine whether there is an effect of the work ethic on the Performance of Employees of the Culture and Tourism Office of Jayawijaya Regency.

Design/methodology/approach - The researchers use quantitative research methods with associative to determine the effect of work ethic on employee performance at the Office of Culture and Tourism of Jayawijaya Regency. This research uses library research instruments, observation, documentation, and questionnaires with a Likert Scale.

Findings - Results revealed a positive and significant influence between the assessment of Work Ethics and Employee Performance at the Office of Culture and Tourism of Jayawijaya Regency.

Practical Implications - The success of an employee's performance can be determined if an agency has a work evaluation system. So an employee must follow the rules and instructions so that later it can be in accordance with the goals of the previous agency.
\end{abstract}

Originality/value -

Keywords Work Ethic, Performance, Employees

Paper Type Research paper (case study)

\section{INTRODUCTION}

Government agencies are one of the government institutions to provide better services that are commonly referred to as (good governance). This research aims to mobilize or use of HR more effectively and efficiently. In this case, employees are employed in agencies, where they determine the success of an organization or agency.

Employees need instructions from agencies so that their work discipline occurs in accordance with the planning and goals of an agency. Such as the Tourism Office which is one of the determinants of the successful development and development of 
Jayawijaya Regency. For this reason, a work ethic is needed to improve better performance so that the results are more optimal.

The success or failure of an employee's performance can be determined if an agency implements a performance appraisal system. Tasmara (2002:9), work ethic is the totality of one's personality and ways of expressing, seeing, believing, and giving meaning to something that drives him to act and achieve optimal charity so that the pattern of the relationship between humans and themselves and between humans and creatures others can be intertwined well. Performance is what employees do and don't do. Employee performance is what influences how many employees contribute to the organization, including among others: the quantity of output, the quality of output, the period of output, attendance at work, and cooperation (Mathis et al., 2002:70).

This research aims to determine whether there is an effect of the Work Ethic on the Performance of Employees of the Culture and Tourism Office of Jayawijaya Regency.

\title{
WORK ETHIC
}

\section{Understanding The Work Ethic}

Work ethic is formed from two terms that are combined, namely ethos and work. Ethos comes from Greek which means a place to live, which then develops into an ethic which means a theory of life or ethics. Work can be interpreted as an activity or someone that involves physical and mental. So the work ethic can be interpreted literally as ethical or physical behavior and mind. In general, work ethic is all good habits based on ethics that must be carried out at work, such as discipline, honesty, responsibility, diligent, patient, insightful, creative, enthusiastic, able to work together, environmentally conscious, loyal, dedicated, being polite, dam etcetera.

Khasanah (2004:8) stated that work ethic is the knitting of values that shape a person's personality in actualizing themselves in forming personality. Mhudofir (1999:56) stated that ethos comes from the Greek "ethos", which is the character (character), way of life, habits of a person, motivation or moral goals of a person as well as their worldview, namely the most comprehensive picture, way of acting or ideas about the order. From the definition above, it can be concluded that a good attitude is formed from within a person such as honest, persevering, and passionate.

\section{The function of Work Ethic}

Work ethic can be seen from several functions, both based on theory and the nature of the description based on opinions such as the following:

a. According to Webster's dictionary quoted by Suseno (2002:64), ethos is defined as a belief that serves as a guide for behavior for someone, a group, or an institution (guiding beliefs of a person, group or institution);

\author{
Vol. 28, No. 01 April 2020 \\ (C) Centre for Indonesian Accounting and Management Research \\ Postgraduate Program, Brawijaya University
}


b. Work ethic can be interpreted as the concept of work or work paradigm which is believed by a person or group of people as good and right which is manifested through their specific work behavior. (Sinamo, 2003:2);

c. In general, the work ethic functions as a permanent driving force of individual actions and activities as an employee; and

d. According to Russian (1989:67), the work ethic function is as follows:

- The person whose actions occur;

- Enthusiastic in activities; and

- Activator.

\section{Purpose of Work Ethics}

Deprivation from the nature of the work ethic is the creation of intelligent, skilled, independent people, having solidarity, hard work, creative, productive, disciplined, future-oriented to create a better life.

\section{How to Grow and Improve the Work Ethic}

Khasanah (2004:76) stated that fostering a work ethic can be through:

- Foster an optimistic attitude;

- Be yourself;

- Courage to begin;

- Work and time; and

- Concentrate on work.

\section{The Role of Work Ethics}

According to Nitisemito (2001:68), work ethic is very important for agencies because with a high work ethic it is expected that workers will work effectively and efficiently. Individuals or groups can be said to have a high work ethic if they show the following signs:

- Have a very positive assessment of human work outcomes;

- Placing a view of work as a very noble thing for human existence;

- Work carried out as a meaningful activity for humans;

- Work is lived as a process that requires perseverance, and is also an important means of realizing ideas; and

- Work is carried out as a form of worship.

\section{Work Ethic Indicator}

The work ethic indicators are as follows:

a. Motivation

Motivation is formed by the attitude (attitude) of employees in dealing with work situations in each organization (situation). Motivation is a condition or energy that moves employees who are directed or directed to achieve organizational goals (Mangkunegara, 2010:61). 
b. Performance Evaluation

According to Nitisemito (2001:75), the assessment of good work performance is very dependent on real mature preparation. Matured means fulfilling four requirements. The first is direct relevance, the second is practical, the third is clarity, and the last is the existence of objective criteria.

c. Organizational Rules

Nitisemito (2001:75) define that organizational regulations are the basis of the implementation of work concerning work relationships, as well as how to do the work. So if the rules are well formulated every employee to commit negligence and escape from responsibility, and if negligence is done repeatedly, it is certain that employees do not have a good work ethic.

\section{Factors That Affect the Work Ethic}

Weber (1958:70) define factors are things that encourage each individual to do something, in this case, if it is associated with a work ethic it can be interpreted that the background of every employee to do something.

\section{PERFORMANCE}

\section{Understanding Performance}

Performance is the quality and quantity of work achieved by an employee in carrying out their duties in accordance with the responsibilities given to him (Mangkunegara, 2010:9). According to Mathis et al. (2002:70), performance is what employees do and don't do. Employee performance is what influences how many employees contribute to the organization including the quantity of output, quality of output, duration of output, attendance at work, and cooperative attitude. Based on some of the opinions above it can be concluded that performance is a result achieved by someone in carrying out the task or burden of responsibility according to the size and standards that apply to each organization.

\section{Elements of Performance}

According to Bernardin (2013:213), the elements of performance are as follows:

- Results of job functions;

- Factors that affect employee performance such as motivation, ability, and role perception;

- Achievement of organizational goals;

- Does not break the law; and

- In accordance with morals and ethics. 


\section{Factors That Affect Performance}

According to Mangkunegara (2010:13), explained that there are two factors that can affect performance, namely the ability factor (ability) and motivation factor (motivation) which formulates that:

a. Ability Factor

Psychologically, this ability is divided into 2 namely potential ability (IQ) and reality ability (knowledge) and (skill).

b. Motivation Factor (Motivation)

Motivation is interpreted as an attitude (attitude) leaders and employees of the work situation (situation) in the organizational environment. The situations referred to include work relations, work facilities, work climate, leader policies, work leadership patterns, and working conditions. According to A. Dale Temple in Mangkunegara (2010:15), the factors that influence performance are internal and external factors, including:

- Internal factors (dispositional), namely factors that are associated with the characteristics of a person. While external factors are factors that affect the performance of someone who comes from the environment. Such as the behavior, attitudes, and actions of coworkers, subordinates or leaders, work facilities, and organizational climate.

- Thus it can be said that performance is a number of outputs (outcomes) produced by a person or group (organization) in the form of material (quantitative) or non-material (qualitative) in a certain period of time.

\section{Concepts of Performance Measurement}

According to Whittaker in Nawawi (2013:233), performance measurement is a management tool used to improve the quality of decision making and accountability. Gomes (2002:142) states that performance measurement criteria based on specific behavior are as follows:

a. Quantity of work, i.e. the amount of labor done in a given period of time;

b. Quality of work, namely the quality of work achieved based on the conditions of readiness;

c. Job knowledge, which is the breadth of knowledge about the job and its skills;

d. Creativeness, namely the authenticity of ideas raised and actions to resolve the problems that arise;

e. Cooperation, namely the willingness to cooperate with other people (fellow members of the organization);

f. Dependability i.e. disciplined and trustworthy awareness in the presence and completion of work;

g. The initiative, which is the enthusiasm to carry out new tasks and to enlarge their responsibilities; and 
h. Personal qualities, namely regarding personality, leadership, hospitality and personal integrity.

\section{Purpose of Performance Evaluation / Evaluation}

Sunyoto in Mangkunegara (2010:10) states that the objectives of performance evaluation or evaluation are as follows:

a. Increase mutual understanding between employees regarding work requirements;

b. Record and acknowledge the performance results of an employee, so that they are motivated to do better, or at least the same achievement as the previous performance;

c. Provide opportunities for employees to discuss their desires and aspirations to raise awareness of careers or to the work carried out now;

d. Define or redefine future goals, so that employees are motivated according to their potential; and

e. Check the implementation and development plan that suits the training needs, specifically the training plan, and then approve the plan if there are things that need to be changed.

\section{Performance Indicators}

According to Mitchel in Sedarmayanti (2001:51), entitled Management of Human Resources and Work Productivity, put forward performance indicators as follows:

a. Quality of work is the quality of work achieved based on the conditions of suitability and high readiness which in turn will give birth to appreciation and progress and organizational development through the systematic improvement of knowledge and skills in accordance with the demands of rapidly developing science and technology;

b. Timeliness, which is related to the suitability of work completion time or not with the planned target time;

c. The initiative is having the self-awareness to do something in carrying out the tasks and responsibilities;

d. Capability, among the several factors that affect a person's performance, it turns out that what can be intervened or treated through education and training is the ability factor that can be developed; and

e. Communication (Communication) is an interaction carried out by superiors to subordinates to express suggestions and opinions in solving problems encountered.

\section{RELATIONSHIP ON WORK ETHIC AGAINST PERFORMANCE}

Mitchel in Sedarmayanti (2008:121) argues that many factors affect employee performance. Most of the factors that encourage or motivate the work of these employees are measured by material in the form of wages and salaries and other compensation, so that it encourages a person to justify any means including 
corruption that is happening a lot today. The motivation of work ethic for employees is needed because it has a direct or indirect influence on employee performance.

With a work ethic, employee morale will be encouraged, so this will be able to bring the agency or organization to achieve goals and progress optimally. So agencies are required to have employees who are not only oriented to the material but also oriented to the afterlife.

\section{RESEARCH CONCEPTUAL FRAMEWORK}

Analysis to determine the effect of work ethic on employee performance can be seen in the following mindset:

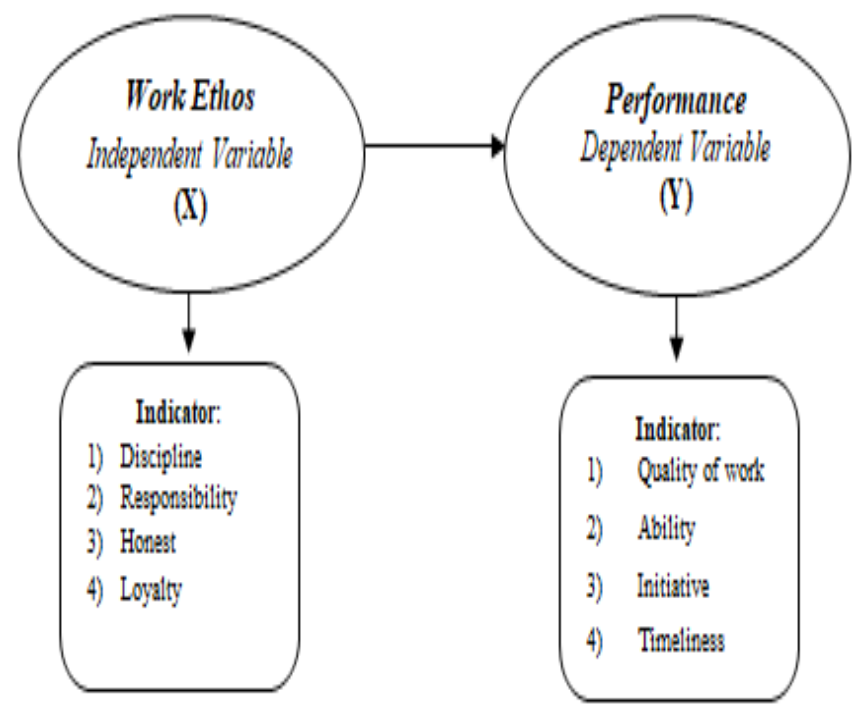

Figure 1.1 Conceptual Framework

In figure 1.1 above, the research flow that will be carried out to analyze the effect of work ethic on the performance of work ethic on employee performance in the Culture and Tourism Office of Jayawijaya Regency is first analyzed, and examined is the work ethic variable where variables This has three indicators to research, namely: 1) discipline, 2) responsibility, 3) honest, 4) loyalty from the results of the variable work ethic, then proceed with an analysis of employee performance variables at the Office of Culture and Tourism of the Jayawijaya Regency which has three indicators, namely: 1) quality of work, 2) ability, 3) initiative, 4) timeliness. The type of research used associative research to find out the relationship between two variables namely Work Ethic and Employee Performance. The reason to choose the Culture and Tourism Office of Jayawijaya Regency because the researcher would know was there a relationship between work 
ethic and the performance on the employee, or which indicator that given effect to the performance of the employee.

The data collection techniques use observation, questionnaires, and literature studies. Testing data analysis used Pearson Product Moment Correlation with Cronbach Alpha Method.

\section{Hypothesis}

a. Hypothesis (Ha)

There is a significant influence between Work Ethic on Employee Performance at the Culture and Tourism Office of Jayawijaya Regency

b. Hypothesis (Ho)

There is no significant effect between the Work Ethic on Employee Performance at the Culture and Tourism Office of Jayawijaya Regency. While the statistical hypothesis is:

Ha: $\mu \neq 0$ there is an influence

Ho: $\mu=0$ there is no effect

\section{RESEARCH RESULT}

The variables analyzed in this research are independent variable data, namely work ethic with Discipline, Responsibility, Honesty, and Loyalty research indicators while the dependent variable data is employee performance with research indicators Work Quality, Ability, Timeliness, and Initiative.

\section{Instrument Validity Test (Validity Test)}

The instrument validity test used was item analysis, which correlated the number of item scores on each item with the total score on each variable. Because validity testing is a level of testing that is able to measure what is to be measured on each research instrument. This can be done by calculating the Pearson Product Moment correlation coefficient. Then the values obtained from the correlation results are interpreted into r-critical. An instrument is said to be valid if the correlation coefficient between item scores and their total scores is at a value of not less than 0.3 (Sugiyono, 2011:134).

a. Variable Assessment of Work Ethics

Based on the results of the validity test of the Work Ethic variable against the items of statements submitted in the research questionnaire (attachment 2), it can be seen in the following table below:

Table 1.1 Test Validity of Work Ethic Variables 


\begin{tabular}{|c|c|c|c|}
\hline $\begin{array}{c}\text { The Bullet } \\
\text { Instrument }\end{array}$ & r-Count & r-Critical & Information \\
\hline & & & \\
1 & 0,595 & 0,355 & Valid \\
2 & 0,769 & 0,355 & Valid \\
3 & 0,698 & 0,355 & Valid \\
4 & 0,554 & 0,355 & Valid \\
5 & 0,669 & 0,355 & Valid \\
6 & 0,483 & 0,355 & Valid \\
7 & 0,752 & 0,355 & Valid \\
8 & 0,680 & 0,355 & Valid \\
9 & 0,592 & 0,355 & Valid \\
10 & 0,491 & 0,355 & Valid \\
11 & 0,512 & 0,355 & Valid \\
12 & 0,746 & 0,355 & Valid \\
13 & 0,501 & 0,355 & Valid \\
14 & 0,682 & 0,355 & Valid \\
\hline
\end{tabular}

Data Sources: Primary 2015 data processing and using Pearson Formula SPSS 16.0 for Windows program

From the table above, it can be seen that all statement items on the Work Ethics variable have valid data because the calculated value is greater than critical which is 0,355 . So that all items of statement on the Work Ethic variable can be used as a basis for further analysis.

b. Employee Performance Variable

Based on the results of the validity test of the Employee Performance variable against the items of statements submitted in the research questionnaire (attachment 2), it can be seen in the following table below: 
Table 1.2 Test of the Validity of Employee Performance Variables

\begin{tabular}{|c|c|c|c|}
\hline The Bullet Instrument & r-Count & r-Critical & Information \\
\hline 1 & 0,502 & 0,355 & \\
2 & 0,765 & 0,355 & Valid \\
3 & 0,484 & 0,355 & Valid \\
4 & 0,723 & Valid \\
5 & 0,438 & 0,355 & Valid \\
6 & 0,706 & 0,355 & Valid \\
7 & 0,765 & 0,355 & Valid \\
8 & 0,764 & 0,355 & Valid \\
9 & 0,738 & 0,355 & Valid \\
10 & 0,715 & 0,355 & Valid \\
11 & 0,495 & 0,355 & Valid \\
12 & 0,471 & 0,355 & Valid \\
13 & 0,454 & 0,355 & Valid \\
14 & 0,558 & 0,355 & Valid \\
15 & 0,497 & 0,355 & Valid \\
16 & 0,770 & 0,355 & Valid \\
17 & 0,764 & 0,355 & Valid \\
18 & 0,621 & 0,355 & Valid \\
19 & 0,653 & 0,355 & Valid \\
20 & 0,710 & 0,355 & Valid \\
21 & 0,815 & 0,355 & Valid \\
\hline
\end{tabular}

Data Sources: Primary 2015 data processing, and using the Pearson Formula SPSS 16.0 for Windows program

From the table above, it can be seen that all items in the Employee Performance variable have valid data because the calculated value is greater than critical, that is 0.355 . So that all items of the statement on the Employee Performance variable can be used as a basis for further analysis.

\section{Instrument Reliability Test (Test Reliability)}

To test the reliability of the research instrument, the Cronbach Alpha method is used, namely by calculating the average of intercorrelations between items in the questionnaire. Variables are said to be reliable if the alpha value is equal to or more than 0.60 (Usman and Akbar, 2006:293).

Table 1.3 Reliability Test Results

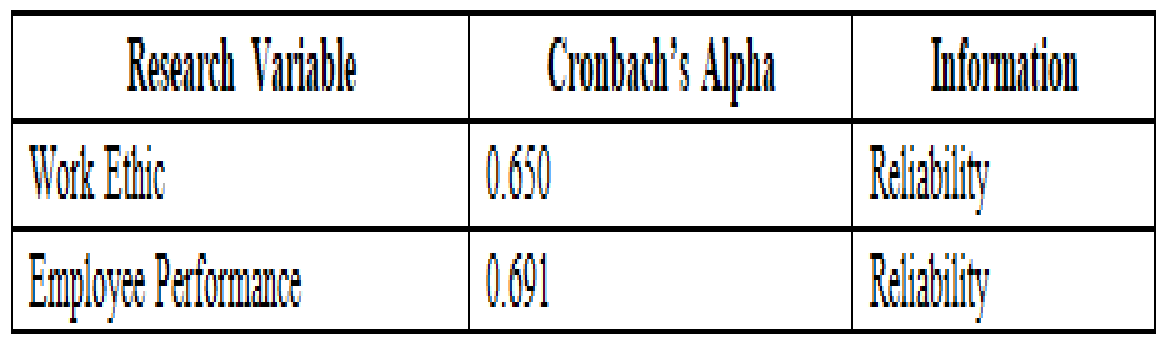

Data Source: Using SPSS 16.0 for Windows

Based on the results of reliability testing, it can be seen that the Alpha value of the work ethic variable is 0.650 and the Alpha value of the employee

Vol. 28, No. 01 April 2020

(C) Centre for Indonesian Accounting and Management Research

Postgraduate Program, Brawijaya University 
performance variable is 0.691 . And this research instrument is greater than > 0.60 which is then compared with the value of r-table at the level of significance $\mathrm{t}=0,000<\alpha=0.05$, with a two-tailed test and the amount of data $\mathrm{n}=31$, the r-table is 0.355 . Therefore the value of $\mathrm{r}=0.650$ and $0.691>\mathrm{r}$ table 0.355 so that it can be concluded that the instrument used is reliable or the items are reliable.

\section{Simple Linear Regression Analysis}

Simple linear regression test using SPSS 16.0 for windows program produces statistical parameters (in appendix 4) it can be seen that the equation of simple linear regression analysis between the effect of work ethic (X), on employee performance (Y) at the Office of Culture and Tourism of Jayawijaya Regency is: $Y$ Y $=\mathbf{1 4 , 8 8 6} 1,184 X$

The level of significance of the work ethic variable shows $t$ count (16.434) > t-table $(0.95 ; 1 ; 29), 1.699$ with Sig. $(0,000)<\alpha(0.05)$, so that Ho is rejected, meaning that a significant regression coefficient or work ethic has a significant effect on employee performance. The use of a simple linear regression equation usually uses the least square method (method of least square) were in determining the values of $\mathrm{a}$ and $\mathrm{b}$ in the regression equation based on the calculations in Appendix 4, the price of $\mathrm{a}=14.886$ and the price of $b=1.184$ is found.

\section{Simple Linear Correlation Analysis}

Based on data from Appendix 4, Figure 1.2 below in the form of scatter diagrams between work ethic variables and employee performance variables shows a directly proportional relationship (positive). This is due to the higher value of the work ethic, the higher the value of employee performance. The form of the graph can be understood to be linear because the distribution of

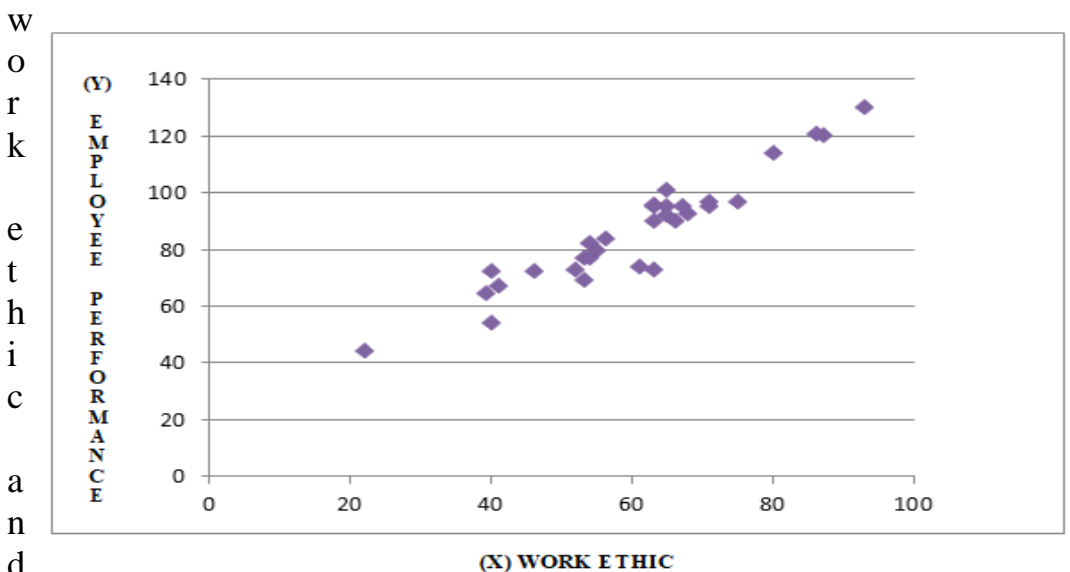


employee performance points can approach a positive straight line, where the direction of writing the line from bottom left to top right.

Figure 1.2 Relationship between Work Ethic and Employee Performance

\section{Correlation Coefficient Analysis}

According to Sugiyono (2012:231) that the guidelines for interpretation of correlation coefficients can be seen in the table as follows:

\section{Table 1.4 Interpretation of Correlation Coefficients}

\begin{tabular}{|c|c|}
\hline Coefficient Intervals & Relationship Level \\
\hline $0,00-0,199$ & Very low \\
$0,20-0,399$ & Low \\
$0,40-0,599$ & Middle \\
$0,60-0,799$ & Strong \\
$0,80-1,000$ & Very strong \\
\hline
\end{tabular}

The correlation test between work ethic variables and employee performance using SPSS 16.0 for windows obtained a statistical value of 0.950. To interpret the value of the relationship between the variable Work Ethic with the Employee Performance variable at the Office of Culture and Tourism Office of Jayawijaya Regency in Jayawijaya District, the authors use the correlation coefficient interpretation guidance table. So the relationship between the two variables, namely the Work Ethic with Employee Performance is included in the category of very strong (between $0.80-1,000$ ). So it can be said that the relationship between the variable Work Ethic with Employee Performance in the Office of Culture and Tourism of the Jayawijaya Regency is very strong.

\section{Analysis Of The Coefficient Of Determination}

Based on the correlation coefficient $(r)=0.950$ shows the relationship of work ethic and employee performance is very high (very strong) and directly proportional (positive). The amount of work ethic contribution to changes in employee performance is based on the coefficient of determination (KP) is $95 \%$. The coefficient of determination $(\mathrm{KP})=0.95(95 \%)$, shows $95 \%$ of the variance in employee performance can be explained by the work ethic and the remaining $5 \%$ is explained outside the work ethic. 


\section{DISCUSSION and ANALYSIS}

From the result of research and data analysis all items in the statement of work ethic variables and employee performance variables have valid. Work ethic variables can affect employee performance due to the four indicators of work ethic variable, one of which is discipline, which can be seen in the field, where the level of employee discipline is high enough by always implementing work discipline, very rarely violates agency regulations because it considers obedience to agency regulations very important in fostering discipline. Based on the results of simple linear regression analysis, it can be seen the effect of the Work Ethic with Employee Performance in the Culture and Tourism Office of Jayawijaya Regency is very strong.

Data analysis to predict the value of the Work Ethic variable used a simple linear regression equation. This regression equation is used to predict how high the value of the Employee Performance variable if the value of the Work Ethic variable is manipulated (changed). Based on the regression equation used to predict employee performance based on work ethic, it can be seen from the results of the product-moment correlation analysis it is known that there is a positive influence and significant between the assessment of Work Ethics and Employee Performance and shows the relationship of work ethic and employee performance is very high (very strong) and directly proportional (positive).

\section{LIMITATIONS AND RESEARCH IMPLICATIONS}

There were limitations of the research, such as: First, the researcher only had a short time to collect the data. Finally, the researcher only used four indicators to found the relationship between work ethic and performance. The results of this research are used to strengthen and enrich existing theories and previous research related to the work ethic and performance, also used as input for the government, especially in the Culture and Tourism Office of Jayawijaya Regency.

\section{CONCLUSION}

From the result of research and discussion, the researcher can provide that there was a positive relationship between work ethic and performance. The one indicator that is very effected was discipline caused the level of this indicator was very high that can be seen in the field, such as they implemented of work discipline with obeyed the regulation. 


\section{REFERENCES}

Alek S. Nitisemito. (2001). The Influence of Loyalty and Work Ethics on the Performance of the Employees of Putra Kudus University, https: //http://pengaruh-loyalitas-dan-etos-kerja-terhadap-kinerja.2012/pdf/. Accessed on Saturday, October 18, 2014, at 03.27 a.m. (1986). The Influence of Organizational Climate, Work Ethic and Work Discipline on the Effectiveness of Organizational Performance in Surakarta Health Polytechnic 2010, http:// mm.unsur.net/content.php?cat=tesis\&id=314. Accessed on Friday, October 17, 2014, at 12.01 a.m.

Anoraga (1992). Relationship Between Organizations Based on Self Esteem and Work Ethics, http://08E00921 / 2 / pdf / Accesed on Wednesday, October 22,2014 , at 12.06 p.m.

Bernardin, et al (2010) The Effect of Work Ethics and Work Discipline on Employee Performance, 27-14-1-PB.pdf - Adobe Reader. Accessed on Monday, October 13, 2014, at 11.37 p.m.

Bungin, B. (2005). Quantitative Research Methodology. Jakarta: Kencana.

Darmadi, H. (2011). Educational Research Methods. Bandung: Alfabeta.

Dessler, G. (2011). Human Resource Management. Jakarta: PT. Index.

Jansen H. Sinamo. (2005). The Effect of Islamic Work Ethic on Employee Performance 2007, Universitas Brawijaya Malang, https: //etos-kerjaislam.pdf/ Accesed on Tuesday, October, 21, 2014, at 05.35 a.m.

James I. Gibson. (1989). The Influence of Organizational Climate, Work Ethic and Work Discipline on the Effectiveness of Organizational Performance in Surakarta Health Polytechnic 2010, http://mm.unsur.net/content.php?cat=tesis\&id=314. Accessed on Friday, October 12, 2014, at 12.03 p.m.

Malayu S.P. Hasibuan. (2005). The Influence of Loyalty and Work Ethics on the Performance of the Employees of Putra Kudus University, https: //production-lo-alality-and-tos-works-for-performers.2012/pdf/. Accessed on Saturday, October 18, 2014, at 15.25 p.m.

Mangkunegara, A. P. (2010). HR Performance Evaluation. Bandung: PT. Refika Aditama.

Regulation of the Minister of Administrative Reform and Bureaucratic Reform of the Republic of Indonesia Number 38 of 2012 concerning Guidelines for Performance Evaluation of Public Service Units.

Rahimah, et al. (1995). Relationship Between Organizations Based on Self Esteem and Work Ethics, USU 2008, https: // 08E00921 / 2 / pdf /. Accessed on Wednesday, October 22, 2014, at 18.15 p.m.

Silalahi, U. (2012). Social Research Methods. Bandung: PT. Refika Aditama.

Siregar, S. (2012). Descriptive Statistics for Research. Jakarta: PT. Rajagrafindo Persada.

Sugiyono (2012). Statistics for Research. Bandung: Alfabeta.

Vol. 28, No. 01 April 2020

(C) Centre for Indonesian Accounting and Management Research

Postgraduate Program, Brawijaya University 
(2012). Quantitative, Qualitative, and R\&D Research Methods. Bandung: Alfabeta.

Surjadi (2012). Development of Public Service Performance. Bandung: PT. Refika Aditama.

Susetyo, B. (2012). Statistics for Research Data Analysis. Bandung: PT. Refika Aditama.

Takdir, S. (2015). Social Statistics, Theory and Applications. Yogyakarta.

Timple, D. (2010). HR Performance Evaluation. Bandung: PT. Refika Aditama.

Uha, I. N. (2013). Organizational Culture of Leadership and Performance. Jakarta: PT. Fajar Interpratama Mandiri.

Law Number 10 the Year 2009 Chapter II Article II Regarding Tourism.

Law Number 43 of 1999 concerning the Principal Personnel of the Republic of Indonesia. 
